\title{
Innovating home visiting to mothers and infants by community health workers: an action-oriented guide
}

Tereza Rebecca de Melo e Lima 1

Paula Ferdinanda Conceição de Mascena Diniz Maia 2

Emanuelle Pessa Valente 3

Francesca Vezzini 4

Giorgio Tamburlini 5

1,2 Instituto de Medicina Integral Prof. Fernando Figueira.Rua dos Coelhos, 300. Boa Vista. Recife, PE, Brasil. CEP: 50.070-550. E-mail: terezarebeca@yahoo.com.br 3-5 Università degli Studi di Trieste. Trieste, Friuli-Venezia Giulia, Italy.

\begin{abstract}
Objectives: to describe the process of development and the structure of an action-oriented guide for home visits (HVs) to mothers and infants by Community Health Workers (CHWs). The guide was adopted in a controlled trial aimed at assessing its efficacy in improving CHW' performance.

Methods: steps to develop the guide included: 1) Review of international and national standards and recommendations for community interventions for maternal and child care; 2) Assessment of perceived needs of CHWs and other Family Health professionals regarding prenatal and postnatal HVs; 3) Identification of elements to construct the guide.

Results: the Guide provides action-oriented instructions for $10 \mathrm{HVs}$ during prenatal and postnatal period up to 9 months instead of the 18 HVs currently recommended by Ministry of Health. Specific tasks for each visit including assessment and promotion of early child development (ECD) and an action-oriented risk classification are introduced as standardized operational practice.

Conclusions: the described approach to guide construction allows adapting the guide contents to the health system context in Brazil and other countries interested in improving quality of HVs by CHWs. The guide, by identifying tasks to be carried out and actions to be taken at each $H V$, provides an innovative approach and represents a requisite for a more efficient and effective use of their time.

Key words Guideline, Community health workers, Home visiting, Maternal and child health, Child development
\end{abstract}




\section{Introduction}

Over the last two decades, strategies to improve maternal, neonatal and child health $(\mathrm{MNCH})$ have drawn increasing international attention. ${ }^{1}$ In Brazil, despite significant progresses and high coverage of care guaranteed by the Health System, some MNCH indicators point out persisting gaps in the quality of care during pregnancy, delivery and postpartum periods. It is the case of e maternal mortality ratio (58.4 maternal deaths/100,000 live births in 20142), and neonatal mortality rate ( 8.9 deaths/1000 live births in 20142), which now represents the main component of infant mortality

Furthermore, there is the need to go beyond mortality reduction and ensure promotion of cognitive and socio-relational development of infants and young children, particularly in the first thousand days of life, considered as an essential window of opportunities for establishing the biopsychosocial basis of health and development up to adult life.1,3

As recognized internationally, actions undertaken at community level play a key role to improve MNCH outcomes, and Home Visits (HVs) stand out as a crucial strategy to reach out for all families, mothers and other caregivers. ${ }^{4}$ Although the role of Community Health Workers (CHWs) in providing HVs is well established in Brazil, current recommendations fail to provide satisfactory guidance for HVs performed by CHWs.

There are indications for $\mathrm{CHW}$ s related to $\mathrm{MNCH}$, but none of these indicates specific tasks and referral criteria for identified problems at each visit. Many of the gaps reported across the literature on CHWs performance related to $\mathrm{MNCH}$ are likely to be the consequence of inadequate guidance and training. Furthermore, early child development (ECD) is still a neglected issue, and is partially tackled only in infants with specific development problems, such as zika virus congenital syndrome.

In an attempt to improve the quality of HVs of $\mathrm{CHWs}$ for $\mathrm{MNCH}$, we developed an action-oriented guide to monitor pregnancy and infancy. We described the development process, the guiding principles and the main information sources of this approach.

\section{Methods}

The Guide and the related training course served as intervention in a controlled trial aimed at assessing their effectiveness in improving the performance of CHWs in prenatal and postnatal period. The trial was part of the project "Innovations in maternal and child care in Pernambuco: evaluating and improving delivery care and home visits to pregnant women and children up to nine months", which was carried out in 3 Health Districts in the city of Recife in Pernambuco State, Brazil. To comply with the timing of the trial, HVs were limited to prenatal period and the first 9 months of life.

The development of the Guide was conducted collaboratively by a multidisciplinary group of experienced professionals in $\mathrm{MNCH}$. It followed three steps aimed at 1) defining the contents of prenatal and postnatal HVs carried out by CHWs; 2) adapting the contents to the tasks of the Family Health Teams (FHTs); 3) identifying the main informing principles to construct the guide. Methods and information sources for the development of the guide are described in Table 1.

Step 1 led to identify current HVs contents that needed to be: reinforced (i.e.: antenatal care, breastfeeding, nutrition, immunization); updated (i.e.: information on care for labor and delivery, prevention of accidents, assessment of warning signs and risk factors for pregnant women and children health); newly introduced to address emerging health needs (i.e.: assessment and promotion of child development and communication with families).

Step 2 assessed the perceived needs of CHWs and other FHTs professionals through interviews, which highlighted that: current training and guidance on daily practice of $\mathrm{HVs}$ and $\mathrm{MNCH}$ are scarce; time for risk assessment and health promotion is insufficient due to the high required number of HVs (each CHW performs about 18 visits from the 1st trimester of pregnancy until the 9th month of life of each child); there is no clear indication of tasks and actions to be taken based on observation. As a consequence, the following needs were identified: better guidance in the translation of observations into actions during HVs; more efficient use of available time for HVs; stronger emphasis on quality rather than number of HVs.

Step 3 allowed, based on the above indications and on international and national guidelines on community interventions for maternal and child care, to adopt the following informing principles for construction the guide: HVs should be limited to key prenatal and postnatal periods and developmental stages of the child; specific tasks to be performed at each HV should be identified; a three-level risk classification system to assess the need for referral should be used; advice on promotion of health and development should be given at each visit. The three level risk classification is color-coded: red (emergency: refer immediately to the Family Health Unit 
Construction of a task-oriented guide for prenatal and postnatal home visits: objectives, methods and information sources.

\begin{tabular}{|c|c|c|c|}
\hline Step & Objectives & Methods & Information sources \\
\hline 1 & $\begin{array}{l}\text { To define the con- } \\
\text { tents of prenatal } \\
\text { and postnatal home } \\
\text { visits }\end{array}$ & $\begin{array}{l}\text { Review of interna- } \\
\text { tional and national } \\
\text { recommendations or } \\
\text { prenatal and post- } \\
\text { natal community } \\
\text { interventions }\end{array}$ & $\begin{array}{l}\text { - Home visits for the newborn child: a strategy to improve } \\
\text { survival (WHO, 2009) } \\
\text { - Optimizing health worker roles for maternal and newborn } \\
\text { health (WHO, 2012) } \\
\text { - WHO recommendations on postnatal care of the mother } \\
\text { and newborn (WHO, 2013) } \\
\text { - WHO recommendations on health promotion interven- } \\
\text { tions for maternal and newborn health (WHO, 2015) } \\
\text { - WHO recommendations on antenatal care for a positive } \\
\text { pregnancy experience (WHO, 2016) } \\
\text { - Standards for improving quality of maternal and newborn } \\
\text { care in health facilities (WHO, 2016) } \\
\text { - O Trabalho do Agente Comunitário de Saúde (Brazil, } \\
\text { 2009) } \\
\text { - Guia Prático do Agente Comunitário de Saúde (Brazil, } \\
\text { 2009) } \\
\text { - Cadernos de Atenção Básica n } 23 \text { - Saúde da Criança: } \\
\text { Nutrição infantil, aleitamento materno e nutrição comple- } \\
\text { mentar (Brazil, 2009) } \\
\text { - Dez passos para uma alimentação saudável para crianças } \\
\text { brasileiras menores de dois anos (Brasil, 2010) } \\
\text { - Cadernos de Atenção Básica nº } 32 \text { - Atenção ao Pré-Natal } \\
\text { de Baixo Risco (Brazil, 2012) } \\
\text { - Cadernos de Atenção Básica n } 33 \text { - Saúde da Criança: } \\
\text { Crescimento e Desenvolvimento (Brazil, 2012) } \\
\text { - Política Nacional de Atenção Básica. Brasília: Ministério da } \\
\text { Saúde (Brazil, 2012) } \\
\text { - Caderneta de Saúde da Criança (Brazil, 2015) } \\
\text { - Caderneta da Gestante (Brazil, 2016) }\end{array}$ \\
\hline 2 & $\begin{array}{l}\text { To adapt home visits } \\
\text { contents and struc- } \\
\text { ture to Family } \\
\text { Health Team context }\end{array}$ & $\begin{array}{l}\text { Assessment of per- } \\
\text { ceived needs by in } \\
\text { depth and semi- } \\
\text { structured inter- } \\
\text { views to relevant } \\
\text { health professionals. }\end{array}$ & $\begin{array}{l}\text { - } 3 \text { Family health physicians } \\
\text { - } 3 \text { Family health nurses } \\
\text { - } 58 \text { Community Health Workers }\end{array}$ \\
\hline 3 & $\begin{array}{l}\text { To identify the main } \\
\text { informing principles } \\
\text { to construct the } \\
\text { guide }\end{array}$ & $\begin{array}{l}\text { Review of interna- } \\
\text { tional and national } \\
\text { problem-based } \\
\text { guidelines for } \\
\text { maternal, neonatal } \\
\text { and child health. }\end{array}$ & $\begin{array}{l}\text { - Chart booklet: Integrated Management of Childhood } \\
\text { Illness (IMCI) (WHO/UNICEF, 2014) } \\
\text { - Manual AIDPI Criança: } 2 \text { meses a } 5 \text { anos (MS Brazil, OPAS, } \\
\text { UNICEF, 2017) } \\
\text { - Quadro de Procedimentos AIDPI Criança: } 2 \text { meses a } 5 \text { anos } \\
\text { (MS Brazil, OPAS, UNICEF, 2017) } \\
\text { - Manual AIDPI Neonatal (Brasil, 2014) } \\
\text { - Quadro de Procedimentos AIDPI Neonatal (MS Brazil, } \\
\text { OPAS, 2014) } \\
\text { - Guidelines for Pediatric Home Health Care (American } \\
\text { Academic of Pediatrics, 2008) }\end{array}$ \\
\hline
\end{tabular}

(FHU) or to hospital), yellow (caution: schedule a priority consultation at the FHU) and green (prevention: maintain the scheduled visits).

\section{Results}

The Guide for Innovative Home Visits to Pregnant
Women and Infants up to nine (9) months is divided into 3 sections: presentation of the Guide and instruction for its use; action-oriented instructions for each HV to pregnant women and infants; and references.

The instructions are in simple language and explain how to use it as a job aid for the daily work 
of HVs. The second section of the Guide provides action-oriented instructions for each $\mathrm{HV}$, for a total of $10 \mathrm{HVs}$, including 5 during prenatal and 5 during the first nine months of life. Prenatal visits include: 1 in the $1^{\text {st }}$ trimester, 2 in the $2^{\text {nd }}$ trimester and 2 in the $3^{\text {rd }}$ trimester. Postpartum visits target both mothers and infants and include: $1^{\text {st }}$ visit in the 1 st week after hospital discharge, $2^{\text {nd }}$ visit in the 1 st month of life, $3^{\text {rd }}$ visit during the $2^{\text {nd }}-3$ rd month, $4^{\text {th }}$ visit during the $5^{\text {th }}-6^{\text {th }}$ month and $5^{\text {th }}$ visit during the $8^{\text {th }}$-9th month. Main contents included in each visit are described in Table 2.

Tasks related to each content (i.e.: Assessment of mother's health and wellbeing) are detailed and include what should be asked, observed and identified by CHWs. For each specific item, there are indications about actions to be taken according to risk-classification.

\section{Discussion}

The international recognition of the crucial role of $\mathrm{CHWs}$ in $\mathrm{MNCH}$ promotion and prevention needs to be reflected in sustained efforts to improve their performance. So far, with few exceptions, reported evidence of these efforts is limited. 5

In Brazil, some interventions to improve the quality of CHWs' performance have been described for pre-natal care, ${ }^{6}$ health problems of children under five years ${ }^{7}$ and breastfeeding promotion. ${ }^{8}$

Table 2

Main contents for each home visit recommended by the Guide for Innovative Home Visits to Pregnant Women and Infants up to nine (9) months.

\begin{tabular}{ll}
\hline Visits & Main Contents \\
\hline
\end{tabular}

Pregnancy:

1 st visit

(1st trimester)

$2^{\text {nd }}$ e 3 rd visit

(2nd trimester)

Antepartum:

4 th e $5^{\text {th }}$ visit

(3rd trimester)
Assessment of mother's health and wellbeing.

Assessment of family environment.

Identification of socioeconomic and psychosocial problems.

Information and advice on preventive practices and prenatal visits.
Postpartum:

1st visit

(1st week after discharge from hospi-

tal)

2nd visit

(1st month of life)
Assessment of mother's health and wellbeing. Assessment of family environment.

Support to breastfeeding.

Information on care for labor and delivery and appropriate place for delivery.

Anticipatory advice on maternal and neonatal most common postpartum problems (and post-partum visit).

Assessment of mother's health and wellbeing

Support to breastfeeding.

Assessment of newborn health and wellbeing.

Information and advice on breastfeeding, essential care of the newborn, most common signs and symptoms

Assessment of support existing in family context and identification of socioeconomic and psychosocial problems

\footnotetext{
Post Natal:

3rd visit

(2nd to 3rd month of life)

$4^{\text {th }} 5^{\text {th }}$ visit

(5th to 6 th month of life)

5th visit

(8th to $9^{\text {th }}$ month of life
}

Assessment of mother and infant health and wellbeing, interaction and general family context.

Advice on feeding and immunizations

Identification of socioeconomic and psychosocial problems

Evaluation of infant development and promotion of practices that favor parentchild interaction

Information and early advice on nutrition, immunization and development. 
However, details regarding the process of planning and development of these interventions are lacking, thus hindering their transferability to other settings.

Our approach addresses some of the current gaps in content and quality of HVs in MNCH. The actionoriented design of the guide defines and standardizes specific tasks for each $\mathrm{HV}$, thus establishing better foundations for improved time management and increased effectiveness in identification of risk factors and warning signs for pregnant women and infants health as well as in providing advice on child development practices to mothers and other caregivers. To our knowledge, there are no reports of guidelines for HVs to pregnant women and infants that indicate specific tasks for each HV, including risk assessment and advice on health promotion.

Although developed for the Brazilian context, this approach could be adopted in other countries to improve CHWs performance. The same development process and structure of the guide could be used to include action-oriented visits until the second and following year of child life.

The Guide is in line with recently WHO recommendations for the optimization of roles and responsibilities of health workers for $\mathrm{MNCH}$

\section{References}

1. United Nations. Transforming our World: The 2030 Agenda for Sustainable Development. New York; 2015. [access 23 Jul 2016]. Available from https://sustainabledevelopment. un.org/post2015/transformingourworld/publication

2. Departamento de Informática do Sistema Único de Saúde. Informações de Saúde (TABNET)/ [homepage na internet]. Brasil; 2001. [access 14 Jan 2017]. Available from http://www2.datasus.gov.br/DATASUS/index.php?area=02

3. Black MM, Walker SP, Fernald RCH,Andersen CT, DiGirolamo AM, Lu C, McCoy DC, Fink G, Shawar YR, Shiffman J, Devercelli AE, Wodon QT, Vargas-Barón E, Grantham-McGregor S; Lancet Early Childhood Development Series Steering Committee.Early childhood development coming of age: science through the life course. Lancet. 2017; 389: 77-90.

4. Gilmore B, Mcauliffe E. Effectiveness of community health workers delivering preventive interventions for maternal and child health in low- and middle-income countries: a systematic review. BMC Public Health. 2013; 13: 847.

5. Tran NT, Portela A, Bernis L, Beek K. Developing capacities of community health workers in sexual and reproductive, maternal, newborn, child, and adolescent health: interventions through task shifting, including training and enabling 'lay' health workers to perform specific interventions otherwise provided only by cadres with more specialized training. ${ }^{9}$

Among the tasks included in the guide, assessment and promotion of ECD is one of the main content innovations. ECD is receiving increasing attention based on mounting evidence on its relevance for individuals along the life course as well as for sustainable societal development and CHWs are seen as key vehicles for ECD promotion. 10

We are aware that a guide may not be sufficient to improve the performance of CHWs. More complex system issues, including the self-attributed role of CHWs and their status vis-à-vis the other health professionals may be difficult obstacles to overcome. Moreover, demand-side issues may hamper the impact of improved CHWs performance on family practices. Having recognized this, we believe that this guide provides a feasible way to standardize, update and expand the contents of HVs, which remain a crucial component of the Family Health Strategy in Brazil and of community health care elsewhere. mapping and review of training resources. PLoS One. 2014; 9 (4): 1-9.

6. Cesar JA, Mendoza Sassi RA, Ulmi EF, Dall'Agnol MM, Neumann NA. Diferentes estratégias de visita domiciliar e seus efeitos sobre a assistência pré-natal noextremo Sul do Brasil. Cad SaúdePública. 2008; 24 (11): 2614-22.

7. Vidal SA, Silva EV, Oliveira MG, Siqueira AS, Felisberto E, Samico I, Cavalcante MGS. Avaliação da aplicação da estratégia da atenção Integrada às doenças prevalentes da infância (AIDPI) por agentes comunitários de saúde. RevBrasSaúdeMatern Infant. 2003; 3 (2): 205-13.

8. Caldeira AP, Fagundes GC, Aguiar GN. Intervenção educacional em equipes do Programa de Saúde da Família para promoção da amamentação. Rev Saúde Pública. 2008; 42 (6): 1027-33.

9. WHO (World Health Organization). Optimizing health worker roles to improve access to key maternal and newborn health interventions through task shifting. 2012. [access 24 Mar 2016]. http://www.optimizemnh.org

10. Chan M. Linking child survival and child development for health, equity, and sustainable development. Lancet. 2013; 381: 1514-5.

Received on February 10, 2017

Final version presented on July 28, 2017

Approved on October 4, 2017 